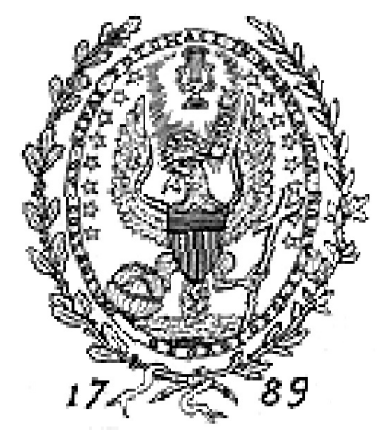

Bioethics Research Library

The Joseph and Rose Kennedy Institute of Ethics

Box 571212, Georgetown University

Washington, DC 20057-1212

202-687-3885; fax: 202-687-8089

bioethics@georgetown.edu

http://bioethics.georgetown.edu

\title{
Landmark Legal Cases in Bioethics
}

\author{
Susan Cartier Poland \\ Revised August, 1997
}

Only a few decades old, the interdisciplinary field of bioethics has developed surrounded by centuries of legal tradition and moral philosophy. Bioethics and the law have weaved back and forth over time influencing each field. Sometimes ethics leads the debate on problematical issues; for example, the Recombinant DNA Advisory Committee at the National Institutes of Health established regulations prior to initiating human gene therapy. At other times, law takes over; Roev. Wade, for example, has polarized and closed public discussion on abortion. Most frequently, however, scientific developments initiate discussion in both fields, as when the announcement of the birth of Dolly - the first cloned mammal - sparked President Clinton to ask the National Bioethics Advisory Commission for a report on cloning.

A back-and-forth pattern also exists within the law itself, this time between legislator and judge. Legislators enact statutes, which apply universally to regulate conduct in society. Judges, on the other hand, interpret statutes and apply them to particular cases to resolve disputes between parties. Case law, as judge-made law is called, that grows in the absence of legislation becomes the common law. Legislatures can change the course of common law development by enacting more law, usually as amendments, but sometimes as repeals. A judge who sees the facts of a case or the law differently may also change the common law. And so the counterpoint between legislator and judge goes.

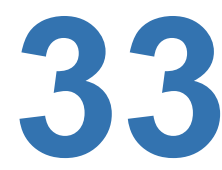


A legal case becomes a landmark in bioethics because of its historical or precedential value to the field. Historical cases reflect judicial reasoning or rationalization that lays the conceptual foundation for a bioethical principle. Perhaps the best known example of this is the focus on the right to self-determination in Schloendorff that led to the development of informed consent. The principle of autonomy in bioethics derives its legal impetus from this line of cases.

A case that acquires landmark status because of its precedential value does so for one of two reasons based on legal precedents. First, the case may be one of "first impression." In the legal sense, that means that the particular case with its facts or issues is the first one that a particular court has confronted within that court's jurisdiction or area of decision-making authority. To be a landmark in bioethics, however, the ordinary sense of "first impression" applies. The first time that a particular bioethical topic has appeared in court for legal resolution makes a case one of "first impression" for bioethics. The case of Baby M on surrogacy contracts illustrates this.

The second way in which a case can achieve landmark status based on precedents involves legal precedent and the jurisdictional basis of the court system. Under the common law system, a preceding case that involves the same or similar facts or issues as a current case must be followed by lower-i.e., less authoritative - courts in the same jurisdiction. That judicial rule of decision making is called stare decisis. It creates an institution of continuity, yet allows for change due to differences in judicial interpretation of facts and issues, which is called distinguishing the case.

All courts under United States jurisdiction must follow the U.S. Supreme Court. By its sheer power of authority, the Court issues opinions that, if they concern bioethical topics, make cases landmarks in bioethics. For example, Roe v. Wade made abortion legal and set off the debate between maternal and fetal rights. Casey later refined, or to some redefined with a discussion of stare decisis, the bioethical underpinnings of Roe by framing the debate as one between maternal rights and state interests.
In law, precedents concern only appellate cases. Trial courts, like that in McFall v. Shimp, handle questions of both fact and law. Appellate courts, like that in Brotherton, hear appeals from the lower trial courts and address legal issues only. Trial judges apply the law to facts, and appellate judges reason about the trial judge's legal interpretation.

Appellate court decisions are the ones most frequently published, either in print or electronically online, for citation. Consequently they are the easiest to locate and retrieve. "Reporters" as the publishers are called can be official or unofficial. Official reporters are public-i.e., government - ones and charge no copyright. Unofficial reporters are private, commercial publishers, which charge a copyright fee.

To update a case, that is, to see if it has been followed, distinguished, or overruled, or to see in what other jurisdictions it has been cited, one uses a service, "Shepard's Citations," which is both in print and online. Such updating is called "shepardizing." Law librarians at the state law library in each state's capital, at local and state bar associations, and at public (and for alumni, private) law schools should be able to help the public locate cases and shepardize.

This Scope Note covers only court cases that fall under U.S. jurisdiction. Foreign cases, such as Canadian or British, have been omitted deliberately. Furthermore, this Scope Note has been limited to civil cases. Civil cases concern duty under tort law and promise under contract law, and breach of duty or breach of promise respectively. No criminal cases are included.

Before its recess in July 1997, the U.S. Supreme Court will issue its first opinion on assisted suicide in the cases of Vacco and Washington (and, following Cruzan, its second opinion on the right to die). Whatever the Court's decision, it certainly will be another landmark legal case in bioethics, to be followed in law and to be debated in bioethics. How it will affect bioethics and the growing legalism of the field remains to be seen.

\section{CASES}




\section{A. Autonomy (Self-determination/Informed Consent/Right to Refuse Treatment/Right to Die)}

Schloendorff v. Society of New York Hospital. 211 N.Y. 125, 105 N.E. 92 (1914).

"Every human being of adult years and sound mind has a right to determine what shall be done with his own body; and a surgeon who performs an operation without his patient's consent commits an assault, for which he is liable in damages." That opinion by Justice Benjamin N. Cardozo became the foundation for the right to self-determination, which underlies the principle of respect for autonomy in bioethics. Mary Schloendorff had agreed only to an examination of a fibroid tumor, which had to be done under ether. She notified one of her doctors that she did not want an operation. While she was anesthetized, the doctors removed a tumor. Postsurgical complications involved gangrene in her left arm and resulted in the amputation of some fingers. Unlike most preceding cases of alleged negligence on the part of doctors, Schloendorff's case was the first to be based on a claim of trespass or unlawful interference with her body. Cardozo noted exceptions to the right to self-determination "in cases of emergency where the patient is unconscious, and where it is necessary to operate before consent can be obtained."

McFall v. Shimp. 10 Pa. D. \& C.3d 90-92 (1978). The Pennsylvania Court of Common Pleas in Allegheny County refused to issue an order whereby McFall, a terminally ill patient with a rare bone marrow disease, could compel Shimp, his cousin and the only suitable donor, to undergo testing and a bone marrow transplant. The court based its decision on the fact that "[t]he common law has consistently held to a rule which provides that one human being is under no legal compulsion to give aid or take action to save another human being or to rescue." The court called the refusal morally indefensible, but argued that forcible submission to a medical procedure would violate the first principle of society, respect for an individual.

Salgo v. Leland Stanford Jr. University Board of Trustees. 154 Cal. App. 2d 560, 317 P.2d 170
(1957).

The term "informed consent" was first used in the Salgo case. Martin Salgo, age 55, suffered from arteriosclerosis and was advised to undergo diagnostic aortography. He was put under anesthesia, his aorta was injected with an $\mathrm{X}$-ray contrast medium, and X-rays were taken of the blocked abdominal aorta. The next morning Salgo discovered that his lower limbs were paralyzed. The court noted that a physician violates his duty to the patient if he withholds any facts necessary to form the basis of an intelligent consent by the patient to the proposed treatment. The court also noted that when discussing risk, the physician has discretion "consistent with the full disclosure of facts necessary to an informed consent."

Canterbury v. Spence. 464 F.2d 772 (D.C. Cir. 1972), cert. denied, 409 U.S. 1064 (1972).

Canterbury v. Spence established an objective standard for the scope of disclosure in informed consent called "the prudent patient test." That test is "what a prudent person in the patient's position would have decided if suitably informed of all perils bearing significance." "[R]isk is thus material when a reasonable person, in what the physician knows or should know to be the patient's position, would be likely to attach significance to the risk or cluster of risks in deciding whether or not to forego the proposed therapy." Disclosure should cover "the inherent and potential hazards of the proposed treatment, the alternatives to that treatment, if any, and the results likely if the patient remains untreated." Factors concerning the significance of danger are "the incidence of injury and the degree of harm threatened." The court noted two exceptions to informed consent. The first involves a patient who is unconscious or otherwise incapable of consent and faced with imminent harm that outweighs any threatened harm from treatment. The second exception arises when the disclosure of risk itself threatens the patient's ability to make a rational decision, complicates treatment, or could cause psychological harm. Jerry Canterbury, age 19, underwent two operations for back pain with his mother's written consent. A myelogram, an injection of dye into the spinal column, identified the vertebra, and a week later, part of that vertebra was removed. The following day 
Canterbury fell off his hospital bed and became totally paralyzed from the waist down several hours later. Dr. Spence had not disclosed the possible risk of paralysis to either the minor patient or the parent.

Bouvia v. Superior Court. 179 Cal. App. 3d 1127, 225 Cal. Rptr. 297 (1986).

Bouvia foreshadows the issue of assisted suicide. Elizabeth Bouvia was born with severe cerebral palsy. At age 28, she was quadriplegic and suffered continual pain from arthritis. After Bouvia had announced her intention to starve herself to death, doctors inserted a permanent nasogastric tube against her will and written instructions. Bouvia was mentally competent and understood the risks. She was neither comatose nor terminally ill. The court ordered enforcement of a patient's exclusive right to refuse any medical treatment or service, even lifesaving or life-prolonging. Her doctors were directed to remove the tube and were prohibited from replacing it without her consent. In the court's opinion, Bouvia's decision is a moral and philosophical decision for her alone to make, not a medical or legal one, and no liability would result from honoring such a decision by a competent and informed patient. With forced feeding, Bouvia had a life expectancy of fifteen to twenty years. Removing the tube would not have been suicide. Instead of causing her death, its removal would have hastened death, because her health had declined to a point where she was no longer able to get sufficient nutrients orally.

In re Quinlan. 70 N.J. 10, 355 A.2d 647 (1976), cert. denied, 429 U.S. 922 (1976).

After mixing barbiturate drugs with alcohol, Karen Quinlan, age 22, suffered brain damage due to insufficient oxygen in the blood. She was not, however, "brain dead." She lay comatose in a persistent vegetative state. She required a nasogastric tube for feeding and was thought to require a respirator for breathing. Her father sought legal guardianship of her in order to authorize discontinuing these life-sustaining procedures. The New Jersey Supreme Court found the constitutional right to privacy to be broad enough to include the patient's decision to decline medical treatment just as it is broad enough to cover the right to abortion in Roe $v$.
Wade. "[T] he state's interest contra weakens and the individual's right to privacy grows as the degree of bodily invasion increases and the prognosis dims." The court appointed the father as guardian to make the best judgment as she would have made in these circumstances.

Superintendent of Belchertown State Schoolv. Saikewicz. 370 N.E.2d 417 (Mass. 1977).

Joseph Saikewicz, age 67 with a mental age of two years and eight months, suffered from leukemia and needed chemotherapy. Under the principle of self-determination and the right to privacy, the court found a basis for the right to refuse treatment. Due to Saikewicz's incompetence, the court substituted its judgment for his and decided against therapy.

Matter of Storar and Matter of Eichner. 420 N.E.2d 64 (N.Y. 1981).

Storar and Eichner are consolidated cases on the right to refuse treatment. John Storar, age 52 with a mental age of 18 months, suffered from bladder cancer and required blood transfusions, not as a cure but to prevent death from other causes. His only relative was his mother, age 77. In Eichner, Brother Fox, a 53-year-old Catholic priest, was in a permanent vegetative state and on a respirator due to cardiac arrest and brain damage caused by a lack of oxygen during a hernia operation. Under common law on self-determination and informed consent, the court found compelling proof that Brother Fox did not want his life prolonged if there was no hope for recovery and so allowed removal of the respirator. But in Storar's case, the court ordered treatment to continue, because a parent cannot deny a child all treatment for a life-threatening condition.

Matter of Conroy. 98 N.J. 321, 486 A.2d 1209 (1985).

Claire Conroy was 84 years old and bedridden in a nursing home. She suffered from severe dementia and physical ailments, including incontinence, arteriosclerosis, diabetes, and hypertension. She required a nasogastric tube for hydration and nutrition. The court decided that even if incompetent she had a right to refuse treatment based on self-determination, informed consent, and privacy. But the court stated that incompetence must be determined 
prior to any surrogate decision maker acting in Conroy's best interests.

Brophy v. New England Sinai Hospital, Inc. 497 N.E.2d 626 (Mass. 1986).

Paul Brophy, a 48-year-old fireman, had suffered a ruptured aneurysm in his brain. Although not "brain dead," he was in a persistent vegetative state and needed a gastronomy tube for food and water in order to survive. His wife sought to remove the tube. Basing the decision on self-determination and privacy, the court substituted its judgment for that of the incompetent Brophy to allow removal of the tube and authorized the wife as guardian to transfer Brophy to a facility that would comply with the patient's wishes and remove the tube.

Matter of Jobes. 108 N.J. 294, 429 A.2d. 434 (1987).

Nancy Jobes, age 31, had been in a car accident. As a result, she not only lost the fetus that she was carrying at the time, but also was brain damaged due to lack of oxygen. She was in a persistent vegetative state. Her husband wanted to remove the tube that supplied hydration and nutrition. The court followed Quinlan, which decided that the family is the appropriate decision maker. Under the substituted judgment doctrine, a family member or close friend could exercise the right to refuse treatment for a patient in an irreversible vegetative state if statements from two independent neurologists showed no possibility of a return to consciousness - i.e., that the state was persistent or permanent.

Cruzan v. Director, Missouri Department of Health. 497 U.S. 261, 110 S. Ct. 2841, 111 L. Ed. 2d 224 (1990).

Cruzan is the first case to reach the U.S. Supreme Court on the issue of a constitutional right to die. As the result of a car accident, Nancy Cruzan, age 30, like Karen Quinlan, was comatose in a permanent vegetative state due to anoxia. While she needed artificial tubal feeding for nutrition and hydration, Cruzan did not need artificial mechanical respiration as was presumed with Quinlan. Her parents sought guardianship over her. The Court addressed the question of the right to refuse treatment as the right not to consent, a corollary to informed consent. Unlike Quinlan's standard of "substituted judgment", the Court adopted the standard of "clear and convincing" evidence, as required in the Eichner case with Brother Fox, as proof of an incompetent patient's wishes where the guardian seeks to discontinue life-prolonging treatment.

Compassion in Dying v. State of Washington. 79 F.3d 790 (9th Cir. 1996), cert. granted, 117 S. Ct. 37 (1996) and Quill v. Vacco. 80 F.3d 716 (2nd Cir. 1996), cert. granted, 117 S. Ct. 36 (1996).

Oral arguments in both cases on assisted suicide were heard in tandem before the U.S. Supreme Court in January 1997. The Compassion in Dying court held that the Washington state statute did not deprive persons who sought physician-assisted suicide of a constitutionally protected liberty interest under the Fourteenth Amendment. That statute prohibited physician-assisted suicide by mentally competent, terminally ill adults. The Quill court held that there was no fundamental right to assisted suicide. However, physicians who are willing to do so may prescribe drugs to be self-administered by mentally competent patients who seek to end their lives during the final stages of terminal illness. The New York state statute in Quill was found to violate equal protection, a different clause of the Fourteenth Amendment.

\section{B. Privacy (Family Autonomy/Maternal-Fetal Rights/Parental Rights)}

Griswold v. Connecticut. 381 U.S. 479, 85 S. Ct. 1678, 14 L. Ed. 2d 510 (1965).

In Griswold, the U.S. Supreme Court recognized for the first time the right to privacy as a penumbra (surrounding area existing in a lesser degree) or penumbral right emanating from specific guarantees in the Bill of Rights and "making the express guarantees fully meaningful." For instance, "the First Amendment has a penumbra where privacy is protected from governmental intrusion." Griswold, the executive director of Planned Parenthood in Connecticut, and the director of a local Planned Parenthood Center, a licensed doctor who also taught at Yale Medical School, were arrested for advising a married couple 
about contraception. A state law prohibited use of contraception or assistance in its use. The court found that as an association of people, marriage is "a relationship lying within the zone of privacy created by several fundamental constitutional guarantees" and so is protected from governmental intrusion.

Roe v. Wade. 410 U.S. 113, 93 S. Ct. 705, 35 L. Ed. 2d 147 (1973).

Roe is the premiere abortion case. With Roe the U.S. Supreme Court established a woman's personal right to abortion under the constitutional right to privacy. According to the Court, life legally begins at birth because "the unborn have never been recognized in the law as persons in the whole sense." "[T] he word 'person', as used in the Fourteenth Amendment (on due process and equal protection) does not include the unborn." Under a trimester system, the decision to abort rests on the medical judgment of the woman's physician in the first three months. Starting with the fourth month of pregnancy, the state may regulate abortion in ways reasonably related to maternal health. After viability, when the fetus is potentially capable of living outside the womb, around 28 weeks and sometimes as low as 24 weeks gestation, the state may regulate or prohibit abortion except when necessary to save the life or health of the mother.

Planned Parenthood of Southeastern Pennsylvania v. Casey. 505 U.S. 833, 112 S. Ct. 2791, 120 L. Ed. 2d 674 (1992).

In Casey, the U.S. Supreme Court reaffirms the essential holdings of Roe, but rejects the trimester framework, resulting in an increased emphasis on viability. Roe's three holdings are: (1) the right to an abortion before viability; (2) the power of the state to regulate abortion after viability; and (3) the state's interests in protecting the health of the mother and the life of the fetus. The Court adopts in Casey the standard of an "undue burden." A state regulation is an undue burden "if its purpose or effect is to place a substantial obstacle in the path of a woman seeking an abortion before the fetus attains viability." In effect, the state has the right to regulate abortion unless a woman can prove that such regulation is an undue burden. In the Court's view, the legal doctrine of stare decisis, a judicial obligation to follow precedent for continuity over time, is "indispensable" but not an "inexorable command." The Court explained that when the Court reexamines a prior decision, like Roe, it considers whether the old rule, such as the trimester framework, is unworkable, inequitable, abandoned, or irrelevant in the context of the present issue, which in Casey was interpreted to be state versus individual interests.

In re A.C. 573 A.2d 1235 (D.C. App. 1990). Court-ordered caesarean sections give the hospital and doctors the authority to override the interests of the mother in favor of those of the fetus. In re A.C. illustrates the conflict in an extreme set of circumstances. A.C. had suffered from cancer since she was a teenager. At age 27 she had married and become pregnant during remission. But 25 weeks into her pregnancy she was found to have an inoperable lung tumor and her condition was terminal. For the sake of the fetus, she agreed to palliative care to extend her life until 28 weeks at which time a caesarean section would be performed. A normal pregnancy is considered to be 40 weeks. At 26 $1 / 2$ weeks, A.C.'s condition worsened, requiring intubation and heavy sedation, and the fetus' condition also worsened, reducing its chance of survival to about 50 percent. The trial court could not ascertain the mother's intent despite her nodding and mouthing words upon regaining consciousness and so ordered surgery. The baby lived two and a half hours. AC. died two days later. Based on the right to bodily integrity and informed consent, the appellate court determined that the trial court had erred by prematurely balancing the interests of the mother against the interests of the state on behalf of the fetus. Prior to the balancing, the trial court should have first determined the patient's wishes directly under informed consent. But if the patient was found to be incompetent or if competency could not be determined, then the court should have made a "substituted judgment" where it determines as best it can what choice A.C. would have made.

International Union, U.A.W. v. Johnson Controls. 499 U.S. 187, 111 S. Ct. 1196, 113 L. Ed. 2d 158 (1991). 
Johnson Controls, the U.S. Supreme Court case on fetal protection, is presently the leading bioethics case for feminists. Because of concern over lead exposure to any potential fetus, Johnson Controls, a manufacturer of car batteries, at first warned and then later prohibited all employees "capable of pregnancy" from certain jobs. The Court determined the employer's exclusion policy for fetal protection was biased and not neutral, because the employer classified employees based on gender and childbearing capacity, not on fertility. Despite evidence of the harmful effects of lead exposure to the male reproductive system, the policy was directed to the unborn of females only.

In re T.A.C.P. 609 So.2d 588 (Fla. 1992).

An anencephalic newborn is not considered "dead" in order to be an organ donor "solely by reason of its congenital deformity." Anencephaly, the absence of large parts of the skull, scalp, and brain, occurs during the first month of gestation. Anencephalics usually only live hours or in the rare case months following birth. The parents of T.A.C.P., also known as Baby Theresa, learned of the condition in the eighth month of pregnancy and agreed to a caesarean section in order to prevent damage to the organs, which they intended to donate. The doctors refused to declare the newborn dead out of fear of criminal liability. Despite a need for infant donor organs, the court declined to expand the common law definition of death, which is the cessation of cardiopulmonary function. A state law had created an exception to the common law for patients on mechanical ventilation, but with a functioning brain stem Baby Theresa did not require life support.

Matter of Baby K. 16 F.3d 590 (4th Cir. 1994), cert. denied, 115 S. Ct. 91, 130 L. Ed. 2d 42 (1994).

Treatment of an anencephalic infant at parental request must be given by the hospital despite its seeming futility. Baby $\mathrm{K}$ was born without a cerebrum and thus permanently lacked consciousness. With only a functioning brainstem, she was expected to live briefly at most. After the second incident of respiratory distress, the hospital sought a court order to allow withholding of ventilator treatment against the mother's wishes. Although the biological father of Baby $\mathrm{K}$ agreed with the hospital, because he was not legally married to Baby K's mother and only distantly involved in Baby K's care, the mother was presumed to be the appropriate decision maker under common law and under both the U.S. and Virginia constitutions. Based on the principles of family autonomy and a presumption in favor of life, the trial court denied the hospital's request unless presented with clear and convincing evidence under Cruzan that to continue treatment would be child abuse or neglect. The appellate court affirmed the lower court's decision, because the Emergency Medical Treatment and Active Labor Act (EMTALA) requires hospitals to provide stabilizing treatment even if hospital physicians considered such treatment morally and ethically inappropriate.

In the Matter of Baby M 109 N.J. 396, 537 A.2d 1227 (1988).

The much publicized custody battle in Baby $M$ between the surrogate mother and the genetic father brought up the issue of parenthood and the limits of a contract. After giving birth, Mary Beth Whitehead, the genetic mother, changed her mind about relinquishing the baby girl to William Stern, the genetic father through artificial insemination, and his wife, Elizabeth Stern, who was to adopt her. The court concluded that the surrogacy contract, which used money to induce adoption - or rather the termination of the mother's parental rights - prior to conception was invalid and unenforceable.

Johnson v. Calvert. 5 Cal. 4th 84, 851 P.2d 776, 19 Cal. Rptr. 2d 494 (1993).

Johnson v. Calvert is a true surrogacy case about the issue of maternity, where the genetic parents, Mark and Crispina Calvert, contracted with a third party, Anna Johnson, to serve as the gestational surrogate. Because Crispina Calvert had had a hysterectomy that left her ovaries intact, she was fertile but unable to carry a pregnancy. Her ovum and her husband's spermatozoan created an embryo in vitro that was then implanted in Johnson. During the pregnancy, the relationship between the Calverts and Johnson became one of distrust. Johnson ultimately refused to surrender the 
infant unless she was paid in full for her services. On the issue of maternity, the court based its decision on intent and decided that the natural mother was Calvert, the genetic mother, who did not intend to donate her ovum but instead intended to parent and raise the child, in short to procreate.

\section{Confidentiality (Physician-Patient Relationship/Third Parties)}

Tarasoff $v$. Regents of the University of California. 17 Cal. 3d 425, 551 P.2d 334, 131 Cal. Rptr. 14 (1976).

Tarasoff is the preeminent case on physician-patient confidentiality and the duty to warn third parties. Two months before university student Prosenjit Poddar murdered another university student, Tatiana Tarasoff, outside her family home, he had told his psychologist at the university hospital of his intent to kill her. At the psychologist's request, university police had detained Poddar, but only briefly because he appeared to be rational. "When a therapist determines, or pursuant to the standards of his profession should determine, that his patient presents a serious danger of violence to another, he incurs an obligation to use reasonable care to protect the intended victim against such danger." This may entail warning the victim or notifying the police, or "whatever steps are reasonably necessary under the circumstances." No one in the Tarasoff family had been notified of the danger. Furthermore, disclosure of confidential physician-patient communication when it is essential to prevent danger to others must be done "discreetly," to protect the patient's privacy "to the fullest extent compatible with the prevention of the threatened danger."

\section{Public Health (Vaccination/Sterilization)}

Jacobson v. Massachusetts. 197 U.S. 11, 25 S. Ct. 358, 49 L. Ed. 463 (1905).

Under the police power of the state, compulsory vaccination does not violate an individual's liberty interest under the Fourteenth Amendment. Because both he and his son had had adverse reactions to the smallpox vaccine, Jacobson refused to be revaccinated as required by a local ordinance of Cambridge,
Massachusetts. That statute exempted a child but not an adult from vaccination if a physician's certificate were provided. The Court held under the principle of self-defense, "a community has the right to protect itself against an epidemic of disease which threatens the safety of its members." Persons and property are subject to reasonable government restraints and burdens as deemed to be "essential to the safety, health, peace, good order and morals of the community." "[G]overnment is instituted 'for the common good, for the protection, safety, prosperity and happiness of the people, and not for the profit, honor or private interests of any one man, family or class of men."

Buck v. Bell. 274 U.S. 200, 47 S. Ct. 584, 71 L. Ed. 1000 (1927).

"Three generations of imbeciles are enough," wrote Justice Oliver Wendell Holmes about the case of Carrie Buck. Age 18, mentally retarded, and institutionalized, Buck was the daughter of a mentally retarded woman, who lived in the same state institution, and was herself the mother of an illegitimate mentally retarded child. The Commonwealth of Virginia sought sexual sterilization of Buck by salpingectomy, the cutting of the fallopian tubes, where fertilization takes place, an operation that would not affect her general health. The case arose under the constitutional issues of due process and equal protection of the Fourteenth Amendment. The Court rationalized that where public welfare often demanded the lives of the state's best citizens, not to ask a lesser sacrifice of one dependent on the state would be strange. The principle behind compulsory vaccination was broadly applied to support sexual sterilization.

\section{E. Property (Person/Embryo/Body Parts)}

York v. Jones. 717 F.Supp. 421 (E.D. Va. 1989). Possession of cryogenically preserved embryos by an in vitro fertilization laboratory and the duty of the lab to account for the embryos creates a bailment (delivery of property in trust to another for a special purpose and for a limited period) relationship between the laboratory and the infertile couple. Steven York and Risa Adler-York wanted the Jones Institute to release their cryogenically preserved embryos 
for transfer to another in vitro fertilization lab for subsequent thawing and implantation. The lab refused to authorize release for transfer. The trial court found under contract law that in the cryopreservation agreement the lab recognized the Yorks' property rights to the embryos and had limited its own control over them.

Davis v. Davis. 842 S.W.2d 588 (Tenn. 1992), cert. denied, 113 S. Ct. 1259 (1993).

Custody or control over frozen embryos and whose custody or control were the questions in Davis v. Davis. A divorcing couple disagreed over the disposition of seven preembryos that were created by in vitro fertilization using the couple's gametes and then stored cryogenically. Following the guidelines of the American Fertility Society, the court concluded that the preembryos were neither persons nor property, but deserved special respect because of the potential for human life and that the husband and wife have the decision-making authority over disposition similar to an ownership interest. The court created a hierarchical structure for disposition of the preembryos: first, the preferences of the genetic parents; second, prior agreement, if the genetic parents are in dispute or otherwise unable to ascertain their preferences; and third, in the absence of a prior agreement, weighing the interests of the parties, with preference given to the person seeking to avoid genetic parenthood in either of two instances: if the other person can become a genetic parent using reasonable means or if the that person wants to donate the preembryos to a third party.

Hecht v. Superior Court (Kane). 16 Cal. App. 4th 836, 20 Cal. Rptr. 2d 275 (1993).

Upon the death of the sperm donor, ownership over cryobanked sperm could be transferred as property by will to another party. Before he committed suicide, William Kane deposited sperm in a sperm bank and authorized release to his longtime companion Deborah Hecht. He had also bequeathed the sperm to her in his will, and in a suicide note he had written that he hoped she would have a child using the sperm. Kane's adult son and daughter as estate administrators sought to have the sperm destroyed. The court concluded that Kane "had an interest, in the nature of ownership, to the extent that he had decision making authority as to the use of his sperm for reproduction" and that such interest was sufficient to be a property interest and thus part of the estate.

Moore v. Regents of the University of California. 51 Cal. 3d 120, 793 P.2d 479, 271 Cal. Rptr. 146 (Cal. 1990), cert. denied, 499 U.S. 936 (1991).

The court held that a patient could sue under informed consent when his cells were used in potentially profitable medical research without his permission. As part of his medical treatment for leukemia, John Moore had his spleen removed. Prior to surgery and without Moore's knowledge, his treating physician had made arrangements with a researcher, both of whom were employed by the University of California, to use Moore's spleen cells for research unrelated to treatment. Sometime during the years of treatment, a cell line genetically traceable to Moore's spleen cells was developed and patented by the university. Later, commercial agreements were negotiated for stock and cash. The court held that because medical treatment decisions are based on the weighing of both benefits and risks to the patient, a doctor seeking a patient's consent to a medical procedure must "disclose personal interests unrelated to the patient's health, whether research or economic, that may affect his medical judgment." However, the court reasoned that Moore's ownership interest in his cells as property was doubtful for three reasons. First, no reported judicial decision supported Moore's claim either directly or by close analogy. Second, state statutes limited any continuing interest or patient control over the cells once excised. Third, the patented cell line, and the products derived from it, were in fact distinct from the original spleen cells and under patent law no longer property of Moore.

Brotherton v. Cleveland. 923 F.2d 477 (6th Cir. 1991).

Due process, not property law, protected a widowed spouse's interests in the body of the deceased spouse. Deborah Brotherton objected to the coroner's removal of her husband's corneas. The hospital had not attempted to notify the coroner of her objection nor had the coroner's office inquired of an objection. After an analysis of property rights in dead bodies, the 
court noted that there was no need to address that question. The court decided that Brotherton's due process rights under the Fourteenth Amendment had been violated, because she had a possessory right to her husband's body and was owed a predeprivation hearing before cornea removal.

\section{F. Patenting (Invention/Creation)}

In re Arzberger. 112 F.2d 834 (C.C.P.A. 1940). A precursor to the issue of patenting organisms, the Arzberger decision is known for its ruling that the Plant Patent Act of 1930 does not encompass bacteria. The Court of Customs and Patent Appeals noted that although bacteria have characteristics of both plants and animals and the scientific authorities classify bacteria as plants, the legislative intent of Congress - and the controlling use - of the word "plant" was its common or popular sense, as tree, shrub or herb, or sup, cutting, or sapling.

Funk Brothers Seed Co. V. Kalo Inoculant Co. 333 U.S. 127, 68 S. Ct. 440, 92 L. Ed. 588 (1948).

The U.S. Supreme Court ruled in Funk that "aggregation of species" of bacteria into one product that has the same effect that each of the species has always had is not invention under patent law. Rhizobia bacteria infect the roots of legumes, like peas and beans, and become nodules, thus allowing the plants to affix nitrogen from the air. Different crops require different bacteria. The general practice was to sell inoculants with one species of the rhizobia bacteria, but Bond, the patent applicant, had created an inoculant with a mixed culture of several species. For a product to be patentable, it must be more than "new and useful;" it must also be a product of "invention or discovery." Packaging bacteria into one inoculant was a product of skill, not invention. "If there is to be invention from such a discovery, it must come from the application of the law of nature to a new and useful end," because "patents cannot issue for the discovery of nature."

Application of Bergy. 563 F.2d 1031 (C.C.P.A. 1977).

Simply because a microorganism is alive does not exclude patentability of a microbiological process according to the ruling of the Court of
Customs and Patent Appeals. Malcolm Bergy, John Coats, and Vedpal Malik sought to patent a microbiological process for making an antibiotic using a microorganism. The court saw "no sound reason to refuse patent protection to the microorganisms themselves - a kind of tool" used in the same way as chemical elements, compounds, and compositions. "[T]he fact that microorganisms, as distinguished from chemical compounds, are alive is a distinction without legal significance" for purposes of patent law.

Diamond, Commissioner of Patents and Trademarks v. Chakrabarty. 447 U.S. 303, 100 S. Ct. 2204, 65 L. Ed. 2d 144 (1980).

Chakrabarty is the U.S. Supreme Court decision on patenting bacteria, Chakrabarty, a microbiologist, genetically engineered a bacterium that could break down the components of crude oil and be useful in cleaning up oil spills. He applied for three patents, one on the method of producing the bacteria, another on the floating material carrying the bacteria, and the last on the bacteria themselves. The Court determined that the bacteria were patentable microorganisms as "manufacture" or "composition of matter" under patent law, because Chakrabarty had "produced a new bacterium with markedly different characteristics from any found in nature and one having the potential for significant utility" As for the Plant Patent Act, the distinction recognized by Congress is "not between living and animate things, but between products of nature, whether living or not, and human-made inventions."

\section{G. Animal Rights}

Sierra Club v. Morton, Secretary of Interior. 405 U.S. 727, 92 S. Ct. 1361, 31 L. Ed. 2d 636 (1972). Key to any case concerning animal rights is the U.S. Supreme Court's holding in Sierra Club. In order to have "standing" to sue in the courts, an aggrieved party must have a personal stake in the outcome of the case, "[T]he 'injury in fact' test requires more than an injury to a cognizable interest. It requires that party seeking review be himself among the injured." The Sierra Club's special interest in conservation as an organization was insufficient to prevent development by Walt Disney Enterprises, Inc., 
of a recreational resort complex in the Mineral King Valley of the Sierra Mountains next to Sequoia National Park.

Lujan v. Defenders of Wildlife. 504 U.S. 555, 112 S. Ct. 2130, 119 L. Ed. 2d 351 (1992).

The organization Defenders of Wildlife sought to have the Secretary of the Interior restore the original interpretation of a federal regulation on endangered species to cover foreign nations and not just the United States and the high seas. The organization through statements by two of its members failed to show injury. The court reiterated the three elements necessary for standing: (1) an "injury in fact" or invasion of a legally protected interest that is concrete and particularized and also actual or imminent, not conjectural or hypothetical; (2) a "fairly traceable" causal connection between the injury and the action of the opposing party, not another third party; and (3) the likelihood and not speculation of a favorable judicial decision as the remedy.

\section{COMMENTARIES}

Allen, Anita L. Autonomy's Magic Wand: Abortion and Constitutional Interpretation. Boston University Law Review 72(4): 683-98, September 1992.

Professor Allen at Georgetown University Law Center comments on the U.S. Supreme Court abortion cases and its interpretation of privacy under the Fourteenth Amendment beginning with Griswold. She accounts for the erosion of Roe based on the Court's perspectives being "backward-looking legal positivism" and "downward-looking moral positivism" where the judges rely respectively on the established positive law, including precedent, and the actual positive values of the community or majority of the community. Other perspectives are forward-looking toward optimal social or economic policies, upward-looking to conform to normative ideals, and inward-looking based on subjective or personal preference.

Annas, George J. Standard of Care: The Law of American Bioethics. New York: Oxford University Press, 1993.

Professor Annas in health law at Boston University uses a case-based approach to bioethics in three areas: the U.S. Constitution, the private sector, and the public sector. In medical malpractice, the term "standard of care" refers to the conduct of a reasonable physician used in treating a patient. If a physician's conduct falls below that standard, then the physician has breached the duty of care and is deemed medically negligent under the law.

Beauchamp, Tom L. The Moral Standing of Animals in Medical Research. Law, Medicine \& Health Care 20(1-2): 7-16, Spring-Summer 1992. Professor Beauchamp at Georgetown University critiques the prevailing view in philosophy and science on moral standing, the cognitivist approach. Under that approach, "[o]ne is a person if and only if one possesses certain cognitive properties that give an entity moral standing." Lack of possession of these properties, such as self-consciousness over time or the capacity of communicate using language, means no moral standing and no rights, including a right to life.

Brown, Barry. Reconciling Property Law with Advances in Reproductive Science. Stanford Law and Policy Review 6(2): 73-88, 1995.

Professor Brown at the Suffolk University Law School explains that courts have been reluctant to extend property interests in sperm, ova, and embryos because the common law abhors treating body parts as property for disposition and sale. He advocates use of property rights, such as control, possession, use, exclusion, profit, and disposition, by the courts and legislatures to create a regulatory framework in light of advances in reproductive science. One problem he considers concerns proprietary rights of both genetic parents over genetic information learned from ex utero testing of an in vitro or cryogenically preserved embryo.

\section{Calabresi, Guido. Do We Own Our Bodies?}

Health Matrix 1(1): 5-18, Spring 1991.

Professor Calabresi, dean of the Yale Law School and known for his writings in law and economics, discusses three issues in the McFall case: the court's use of precedent based on the view of society as autonomous and individualistic, or in other words, libertarian versus communitarian; differing judicial interpretations of the U.S. Constitution and 
legislatively coerced donation of body parts; and the consequences of a system ascribing ownership of body parts to those with need and not to those with possession.

\section{Callahan, Daniel. Escaping from Legalism: Is It}

Possible? Hastings Center Report 26(6): 34-5, November-December 1996.

Callahan, former director of the Hastings Center, laments legalism-i.e., "the translation of moral problems into legal problems." The presence of the law inhibits serious public moral debate in his view.

Capron, Alexander Morgan. Morality and the State, Law and Legalism. Hastings Center Report 26(6): 35-7, November-December 1996.

Professor Capron comments on Callahan's concern over legislated morality. He believes that public discussion increases when "state enforcement of a prohibition would entail unacceptable costs." Capron believes that court decisions that support the view of a particular religion stifle open moral discourse.

Capron, Alexander Morgan. The Burden of Decision. Hastings Center Report 20(3): 36-41, May/June 1990.

Capron's article is an adaptation of his keynote address to the National Conference of the State Judiciary on Bioethical Issues given 7 September 1989. He believes that just because "good reasons certainly exist for courts to become involved in some bioethics cases," there is no reason to shift routinely decision making from the doctor to the judge, which would only be another form of paternalism.

Capron, Alexander Morgan. Law and Bioethics. In Encyclopedia of Bioethics, rev. ed., ed. Warren Thomas Reich, pp. 1329-35. New York: Simon \& Schuster Macmillan, 1995.

Capron focuses on "the law as a practical force in shaping and defining bioethics." This encyclopedia entry covers three topics: "What is the law?," "The impact of law on bioethics," and "Law and bioethics as a field." $\mathrm{He}$ concludes that the law and bioethics will continue to interact with each other.

Capron, Alexander Morgan, and Michel, Vicki. Law and Bioethics. Loyola of Los Angeles Law
Review 27(1): 25-40, November 1993.

Capron and Michel, both at the University of Southern California Law Center, begin with a description of bioethics as an interdisciplinary field that covers the ethical problems of modern medicine and biotechnology but without a single accepted methodology, such as principlism or casuistry, due to moral pluralism. Most of their article addresses "law and bioethics" as neither a subject area within the law nor a subset of law and philosophy. The law has influenced the development of bioethics as a discipline, more so than any other field, with economics coming the closest. For example, the legal concepts of privacy and liberty influenced the ethical principle of autonomy, and the bioethical concept of "proportionality" was introduced into the law through the Quinlan case. Therefore bioethics differs from most other disciplines. Also, bioethics is equally academic and applied. Using the problem of life support for noncompetent patients, the authors illustrate the tension between law and bioethics over decision making about treatment.

\section{Jecker, Nancy S. Conceiving a Child to Save a} Child: Reproductive and Filial Ethics. Journal of Clinical Ethics 1(2): 99-103, Summer 1990.

Jecker proposes six ethical guidelines that govern personal, and in particular filial, relationships by examining the Ayala case. After a vasectomy reversal, the Ayalas, both in their early to mid-forties, conceived a child, daughter Marissa, to save an older child, teenage daughter Anissa. Anissa suffered from terminal leukemia and needed a bone marrow transplant to survive. Neither the parents nor the brother were compatible, and a nonrelated compatible donor could not be found.

Meilaender, Gilbert. Less Law? Or Different Law? Hastings Center Report 26(6): 39-40, November-December 1996.

Meilaender disagrees with Callahan that discussion ends when moral problems are translated into legal ones. Noting that "law and morality inevitably intersect," he believes that open discussion may not be possible unless concerns are acknowledged to be relevant to both morality and the law.

O'Connor, John J. The Commercialization of 
Human Tissue-The Source of Legal, Ethical and Social Problems: An Area Better Suited to Legislative Resolution. Loyola of Los Angeles Law Review 24(1): 115-69, November 1990.

The student author of this comment on the Moore case argues that in cases involving commercial use of human tissue, informed consent does not advance the interests of all parties. Two parties are private, the individual who is the source of the tissue and the biotechnology industry that seeks to patent the invention; and two parties are public, the public itself, which gains from the research and development behind the patent application, and the federal government, who issues the patent. He proposes legislation to allow flat fee compensation to individuals with unique tissue as a way of regulating contracts between private parties.

Pellegrino, Edmund D., and Sharpe, Virginia Ashby. Medical Ethics in the Courtroom: The Need for Scrutiny. Perspectives in Biology and Medicine 32(4): 547-64, Summer 1989.

Pellegrino and Sharpe, both at Georgetown University, look at how the law and medical ethics intersect in court decisions, such as Brophy, Bouvia, and Jobes, concerning withdrawal or withholding life-prolonging treatment. They highlight the use of medical-ethical literature as evidence, judicial rationalization based on ethical points of view, and the court's duty to the state to protect the integrity of the medical profession.

Pence, Gregory E. Classic Cases In Medical Ethics; Accounts of Cases That Have Shaped Medical Ethics, with Philosophical, Legal, and Historical Backgrounds, 2d ed. New York: McGraw-Hill, 1995.

Professor Pence, a philosophy professor at the medical school at the University of Alabama in Birmingham, more loosely describes "cases" as medical ones of interest to philosophers. Not all of his selections were resolved in court. He divides his book into four areas: death and dying, the beginning of life, research and experimental treatments, and individual rights and the public good. Each "case" making up the 18 chapters includes a discussion of the ethical issues involved.
Schneider, Carl E. Bioethics and the Family: The Cautionary View From Family Law. Utah Law Review 1992(3): 819-47, 1992.

This article is part of a symposium on "Ethics, Bioethics, and Family Law." Professor Schneider at the University of Michigan Law School argues that family law has neither an approach nor a vocabulary that can be used to analyze bioethical problems. He looks at several conceptual approaches (protective function, official discretion, family authority, rights discourse, and the facilitative function) as trends away from moral discourse, where family law definitions and beliefs were clearly defined and coherent and required courts to put legal principles into moral terms and goals. Courts had referred decisions to the family as the appropriate decision maker under "family autonomy." That has been weakened due to the "standards problem." The "standards problem" is that societal standards for governing family relationships cannot or should not be written due to cultural and individual variations. "[P] eople disagree about how families ought to be organized and run and . . . those disagreements often reduce to unresolvable disputes over unverifiable beliefs." Furthermore, the courts' use of precedent creates a slippery slope in defining who constitutes a family based on "functional equivalents" of spouses, parents, and children.

Schneider, Carl E. Bioethics in the Language of the Law. Hastings Center Report 24(4): 16-22, July-August 1994.

Schneider asserts that the language of the law goes beyond terms to include "conceptual, organizing ideas." He sees law as a language of social regulation, a method that has been developed by the common law process of court interpretation and legislative response. Drawbacks to using the law to analyze bioethical problems involve: first, the inaptness of idioms such as tort law, which states minimum duties and not aspirations; second, the system of precedence and principle creating a judicial reluctance to define rights; and third, an incomplete picture of society due to the limited number of plaintiffs and of precedential cases.

Schneider, Carl E. Cruzan and the Constitutionalization of American Life. Journal 
of Medicine and Philosophy 17(6): 589-604, December 1992.

Schneider argues against judicial formulation of a policy on withdrawal of medical care from incompetent patients because too many interests, "the patient's, the patient's family's, medical practitioner's, society's economic interests, society's social and moral interests," are involved. He believes that the U.S. Supreme Court's analysis of constitutional rights, using Cruzan and privacy as an example, is "poorly suited to formulating policy in areas of social complexity and difficulty."

Schneider, Carl E. Moral Discourse, Bioethics, and the Law. Hastings Center Report 26(6): 37-9, November-December 1996.

Schneider writes of the "tutelary" discourse of the courts, when acting as interpreters of the Constitution, as being "instinct with coercion" and "a forbidding finality." In his view, the Roe decision prematurely cut off social debate on abortion. The decisions of the Courts of Appeal of the Ninth and Second Circuits on physician-assisted suicide he sees as "tutelary discourse misplaced" and "moral discourse of the most peremptory kind."

Strudler, Alan. Self-Determination, Incompetence, and Medical Jurisprudence. Journal of Medicine and Philosophy 13(4): 349-65, November 1988.

A research scholar at the University of Maryland, Strudler defends the courts' ascription of the right to self-determination to incompetents, such as Saikewicz and Quinlan, even when they are personally incapable of exercising the right. By using the language of "choice," the courts create a "fundamental" individual right that requires a "compelling" state interest to overcome. One school against this judicial practice are the cognitivists, philosophers who argue that certain cognitive abilities other that simply being a member of the human race are necessary conditions of personhood.

Rhoden, Nancy K. Cesareans and Samaritans. Law, Medicine \& Health Care 15(3): 118-25, Fall 1987.

The late Professor Rhoden takes the position that the courts should not order caesarean sections to be the morally and legally correct decision. In her view, mandatory rescue of the fetus is state benevolence that imposes on the rights of the mother to self-determination, informed consent, and choice.

Steinbock, Bonnie. Sperm as Property. Stanford Law and Policy Review 6(2): 57-71, 1995.

Steinbock, a professor of philosophy at the University of Albany, State University of New York, focuses on the Hecht case in discussing the moral and legal arguments for and against treating the body as property. In a case of first impression like this, either judges can make new law according to the positivist school of jurisprudence (H. L. A. Hart, The Concept of Law (1961), Chapter 7) or judges are required to apply existing legal principles, according to the rights school (Ronald Dworkin, Taking Rights Seriously (1978), Chapter 4). In her view, the purpose or use of the body part must be identified before the question of whether it is property can be answered.

Susan Cartier Poland, J.D., is Legal Research Associate at the National Reference Center for Bioethics Literature. 